\title{
HUBUNGAN ANTARA ATTACHMENT STYLE DAN SELF-ESTEEM DENGAN KECEMASAN SOSIAL PADA REMAJA
}

\author{
Noer Lailatul Ma'rifah dan Meita Santi Budiani \\ Program Studi Psikologi Universitas Negeri Surabaya \\ e-mail: ita_peha@yahoo.com
}

\begin{abstract}
Relationship between Attachment Style, Self-Esteem and Social Anxiety Among Adolescence. The purpose of this study was to examine the relationship between attachment style, self-esteem and social anxiety among adolescence. Attachment style, self-esteem, and social anxiety scales were used to collect data from students of class Xin a senior high school in Madiun, East Java. Using purposive sampling technique, 58 students were chosen to participate in this study. Path analysis was employed to examine the relationship between attachment style, selfesteem and social anxiety; attachment style and social anxiety; and self-esteem and social anxiety. The result showed that there are negative correlation between attachment style, self-esteem and social anxiety. Attachment style have both direct and indirect effect to social anxiety while selfesteem only have a direct effect to social anxiety.
\end{abstract}

Keywords: Attachment style, self-esteem, social anxiety, adolescence.

\begin{abstract}
Abstrak: Tujuan dari penelitian ini adalah untuk menguji hubungan antara attachment style dan self-esteem dengan kecemasan sosial. Penelitian ini menggunakan pendekatan kuantitatif dengan metode korelasi. Peneliti menggunakan skala attachment style, self-esteem, dan kecemasan sosial sebagai instrumen untuk mengumpulkan data. Data diambil dari siswa SMA Negeri 1 Dagangan Madiun, yang duduk di kelas X. Peneliti mengukur attachment style, self-esteem dan kecemasan sosial pada 58 siswa yang telah terpilih dengan menggunakan teknik purposive sampling. Dilakukan analisis jalur untuk menguji hubungan antara attachment style dan self-esteem dengan kecemasan sosial, attachment style dengan kecemasan sosial, dan self-esteem dengan kecemasan sosial. Hasilnya menunjukkan bahwa ada hubungan negatif yang signifikan antara attachment style dan self-esteem dengan kecemasan sosial. Attachment style memiliki pengaruh langsung maupun tidak langsung terhadap kecemasan sosial sementara self-esteem hanya memiliki hubungan langsung terhadap kecemasan sosial.
\end{abstract}

Kata kunci: Attachment style, self-esteem, kecemasan sosial, remaja.

Perkembangan manusia terjadi mengikuti pola tertentu yang terdiri dari beberapa periode. Pada periode remaja, manusia mengalami masa transisi dari masa kanak-kanak menuju masa remaja. Transisi perkembangan pada masa remaja berarti sebagian perkembangan masa kanak-kanak masih dialami namun sebagian kematangan masa dewasa sudah dicapai (Hurlock, 1990). Hurlock (1990) menambahkan bahwa awal masa remaja berlangsung kira-kira dari 13-16 tahun atau 17 tahun, dan akhir masa remaja bermula dari usia 16 atau 17 tahun sampai 18 tahun. Perkembangan yang dialami oleh manusia pada masa remaja meliputi perkembangan fisik dan perkembangan psikososial. Perkembangan psikososial meliputi usaha untuk pencarian identitas, perkembangan seksual dan perkembangan sosial dengan keluarga, teman sebaya dan masyarakat (Papalia, Olds, \& Feldman, 2008).

Remaja lebih banyak melakukan kegiatan di luar rumah seperti kegiatan sekolah, ekstra kurikuler dan bermain dengan teman. Dengan demikian, wajar jika banyak remaja yang lebih dekat dengan teman sebayanya dan menghabiskan waktu lebih banyak dengan mereka. Kedekatan dengan teman sebaya ini tidak lantas membuat remaja 
bebas dari rasa cemas ketika berada di lingkungan sosial. Rasa cemas ketika berada dalam lingkungan sosial ini sering kali disebut dengan istilah kecemasan sosial. Kecemasan sosial adalah ketakutan yang berlebihan terhadap evaluasi negatif dari orang lain. Orang dengan kecemasan sosial takut untuk mengatakan atau melakukan sesuatu yang memalukan atau membuat dirinya merasa hina (Nevid, 2005). Kecemasan sosial ditandai dengan 3 komponen, yaitu physiological components (seperti badan berkeringat dan muka merah), cognitive/perceptual components (berupa keyakinan bahwa seseorang menilai negatif terhadap dirinya), dan behavioral components (dalam bentuk upaya seseorang untuk menghindari situasi yang membuat dia merasakan kecemasan sosial).

Kecemasan sosial dapat memiliki pengaruh pada fungsi sehari-hari dan kualitas hidup seseorang (Nevid, 2005). Kecemasan sosial dalam kasus yang terjadi pada sebagian siswa Sekolah Menengah Atas (SMA) dapat menghalangi mereka untuk menyelesaikan sasaran pendidikannya dan jika hal ini terus berlanjut dikhawatirkan akan menghalangi mereka untuk maju dalam kariernya. Kecemasan sosial salah satunya dipengaruhi oleh penilaian seseorang terhadap dirinya sendiri. Kecemasan muncul ketika seseorang merasa bahwa mereka merasa kurang memiliki kemampuan yang dibutuhkan untuk keberhasilan dalam menjalin hubungan sosial (Dayakisni \& Hudaniyah, 2009). Parr dkk. (2009) menyatakan bahwa banyak kasus kesulitan berpartisipasi sosial lebih berkaitan dengan penilaian subjektif mereka terhadap penampilan diri daripada keterampilan sosial. Kecemasan sosial lebih dipengaruhi oleh ketakutan evaluasi secara umum, baik itu evaluasi negatif maupun evaluasi positif (Weeks, 2010).

Dayakisni \& Hudaniyah (2009) menyatakan bahwa kecenderungan seseorang untuk menilai dirinya sendiri ini berkaitan dengan tinggi rendahnya self-esteem. Selfesteem sendiri merupakan kepercayaan akan kemampuan diri sendiri untuk berpikir dan mengatasi tantangan dasar dalam hidup serta kepercayaan pada hak untuk bahagia, perasaan berharga, pantas untuk menyatakan kebutuhan dan keinginan, dan menikmati buah dari usaha-usaha yang telah dilakukan (Branden, 1992). Pada remaja yang memiliki self-esteem tinggi akan cenderung menilai dirinya berharga, dicintai, dan mendapatkan perhatian dari orang-orang di sekitarnya. Sementara pada remaja dengan self-esteem rendah cenderung berpendapat sebalikya.

Self-esteem mengandung dua pilar utama, yaitu self-efficacy dan self-respect. Self-efficacy berperan sebagai kompetensi fundamental untuk mengatasi tantangan dalam hidup, meliputi keyakinan pada pikiran seseorang dan prosesnya. Sedangkan pengalaman dari self-respect membuat kemungkinan yang penuh dengan kebaikan, perasaan non-neurotis dengan individu lain, dan persahabatan yang mandiri dan saling menghargai. Self-esteem yang rendah memiliki andil dalam kemunculan kerentanan psikologis menyeluruh (Durand \& Barlow, 2006).

Pada dasawarsa terakhir, para ahli perkembangan mulai menjelajahi peran "secure attachment" (kelekatan yang aman), misalnya dengan orang tua terhadap perkembangan psikologis remaja. Mereka yakin bahwa attachment dengan orang tua pada masa remaja dapat membantu kompetensi sosial dan kesejahteraan sosial remaja, sebagaimana tercermin dalam ciri-ciri seperti harga diri, penyesuaian emosional, dan kesehatan fisik yang baik (Santrock, 2002). Attachment adalah ikatan kasih sayang dari seseorang terhadap pribadi lain yang khusus. Menurut teori attachment Bowlby (dalam Santrock, 2002), pengalaman awal dengan pengasuh utama diinternalisasi oleh anak- 
anak untuk membentuk internal working models, yaitu struktur kognitif yang bertindak sebagai prototip untuk hubungan selanjutnya di luar keluarga. Internal working models pada remaja mempengaruhi interaksi mereka dengan significant other (Surcineli, 2010). Penelitian Liliana (2009) tentang attachment remaja akhir putri menyimpukan bahwa attachment yang cukup baik dengan ibu berkaitan dengan kepercayaan subjeknya bahwa orang lain menganggap positif tentang dirinya dan percaya bahwa orang lain mencintai dan menghargainya. Hasil penelitian Surcinelli (2010) juga menunjukkan bahwa secure attachment pada orang dewasa diasosiasikan dengan kesehatan mental yang lebih baik. Sementara insecure attachment ditandai dengan pikiran negatif tentang self yang diasosiasikan dengan nilai depresi dan kecemasan yang lebih tinggi.

Menurut Horney (dalam Feist \& Feist, 2008), manusia yang tidak pernah terpuaskan kebutuhannya atas cinta dan kasih sayang selama masa kanak-kanak akan mengembangkan permusuhan dasar terhadap orang tua. Akan tetapi anak jarang mengekspresikan dengan jelas kebencian ini sebagai kemarahan, bahkan mereka sering merepresi kebencian terhadap orang tua dan orang tua tidak pernah menyadarinya. Kebencian yang direpresi tersebut pada gilirannya mengarah kepada rasa tidak aman yang mendalam dan sebuah perasaan cemas yang samar-samar. Keluarga adalah tempat yang penting dimana anak memperoleh dasar dalam membentuk kemampuannya agar kelak menjadi orang berhasil di masyarakat. Dapat diketahui bahwa keluarga menjadi tempat yang paling penting bagi remaja untuk pembentukkan sosial dan emosional remaja khususnya bagi kondisi remaja yang sedang memasuki masa perubahan atau transisi (Gunarsa \& Gunarsa, 2004). Untuk itu peneliti mengambil penelitian untuk menguji hubungan antara attachment style dan self- esteem dengan kecemasan sosial pada remaja. Penelitian ini menarik karena dapat mengkaji tentang bagaimana peran keluarga dalam memberikan attachment dan self-esteem remaja terhadap kecemasan sosial remaja dan dampak-dampak yang ditimbulkan dari kecemasan tersebut, seperti terhambatnya proses belajar remaja, terhambatnya proses aktualisasi diri remaja, kurangnya hubungan sosial remaja dengan teman-teman sebaya maupun inter-generasinya.

Berdasarkan latar belakang masalah yang telah dikemukakan di atas, maka rumusan masalah yang diangkat dalam penelitian ini adalah sebagai berikut: "Adakah hubungan yang signifikan antara attachment style dan self-esteem dengan kecemasan sosial baik secara langsung maupun tidak langsung?" Hipotesis yang diambil penelitian ini adalah ada hubungan yang signifikan antara attachment style dan self-esteem dengan kecemasan sosial pada remaja baik secara langsung maupun tidak langsung.

\section{METODE}

Pendekatan kuantitatif dengan metode korelasional digunakan penelitian ini untuk menguji hubungan antara dua variabel independen yaitu attachment style dan selfesteem dengan satu variabel dependen yaitu kecemasan sosial.

\section{Sampel}

Populasi dalam penelitian ini adalah siswa kelas $\mathrm{X}$ di sebuah SMA Negeri di Madiun Jawa Timur berusia 15-18 tahun yang memiliki kriteria kecemasan sosial yang paling mendekati kriteria kecemasan sosial dalam definisi operasional. Jumlah keseluruhan siswa kelas X di SMA tersebut adalah 187 siswa dengan jumlah siswa lakilaki sebanyak 82 siswa atau $43,8 \%$ dan siswa perempuan sebanyak 105 atau 56,2\%. Dari 
populasi itu terpilih sampel sebanyak 61 siswa atau $32 \%$ dari total populasi dengan teknik pengambilan sampel purposive sampling yang dilihat dari kelas yang rata-rata siswanya mengalami kecemasan sosial tanpa memperhatikan jenis kelamin. Karena dalam pelaksanaannya ada tiga sampel yang tidak datang maka sampel total dari penelitian ini adalah 58 siswa.

\section{Teknik Pengumpulan Data}

Teknik pengumpulan data dalam penelitian ini menggunakan angket/ kuesioner tertutup berupa skala attachment style, skala self-esteem dan skala kecemasan sosial. Kuesioner terdiri dari 4 pilihan yang direspon subjek dengan memilih satu dari keempat pilihan secara langsung, yaitu Sangat Sesuai (SS), Sesuai (S), Tidak Sesuai (TS), dan Sangat Tidak Sesuai (STS). Validitas instrumen ditentukan dengan melihat aitem yang memiliki harga $r_{\text {hitung }}$ lebih besar atau sama dengan 0,30 tabel nilai koefisien validitas dengan taraf signifikansi $5 \%$ (Azwar, 2008).

Instrument attachment style disusun berdasarkan indikator-indikator yang berasal dari dua konsep attachment style, yaitu secure dan insecure attachment. Dalam kategori insecure attachment terdapat tiga kelompok dengan karakteristik yang berbeda, yaitu preocupied/ambivalent attachment, dismissing/avoidant attachment, dan fearful attachment. Keempat attachment style tersebut dapat dilihat melalui dua aspek, yaitu persepsi terhadap figur orang tua dan persepsi terhadap diri dan orang lain. Persepsi terhadap orang tua diturunkan ke dalam tiga indikator, yaitu kepedulian orang tua, komunikasi dengan orang tua, dan citra orang tua di mata individu. Sementara persepsi terhadap diri dan orang lain diturunkan ke dalam empat indikator, yaitu perasaan dicintai, kepercayaan pada diri dan orang lain, ketergantungan, dan keintiman. Instrumen attachment style disusun dalam bentuk pilihan jawaban yang harus diisi responden dengan memberikan ranking pada setiap pilihan jawaban. Ranking yang diberikan berkisar antara 1-4 yang menunjukkan respon sangat tidak sesuai sampai sangat sesuai. Skor total dari ranking yang diberikan pada pilihan jawaban nantinya akan dilihat untuk menentukan kecenderungan attachment style responden berdasarkan skor yang tertinggi di antara keempat attachment style yang ada. Hasil uji validitas menunjukkan bahwa dari 21 aitem, 18 aitem dinyatakan valid karena koefisiennya lebih besar atau sama dengan 0,3, dan 3 aitem gugur karena koefisiennya kurang dari 0,3 .

Instrumen self-esteem disusun dalam bentuk skala likert berisi indikator-indikator seperti yang telah diungkapkan dalam definisi operasional seperti life consciously, tanggung jawab, integritas, self-essertiviness, selfacceptance, dan life purposefully. Hasil uji validitas menunjukkan bahwa dari 64 aitem, 43 aitem dinyatakan valid karena koefisiennya lebih besar atau sama dengan 0,3, dan 21 aitem gugur karena koefisiennya kurang dari 0,3.

Instrumen kecemasan sosial berisi indikator-indikator kecemasan sosial yang terdiri dari 3 komponen, yaitu komponen perilaku, perasaan, dan respon fisiologis. Masing-masing aspek memuat indikator seperti yang telah dipaparkan dalam definisi operasional. Hasil uji validitas menunjukkan bahwa dari 46 aitem, 31 aitem dinyatakan valid karena koefisiennya lebih besar atau sama dengan 0,3, dan 15 aitem gugur karena koefisiennya kurang dari 0,3 . Penelitian ini menggunakan bantuan program SPSS for windows versi 17 untuk menguji reliabilitasnya. 


\section{Teknik Analisis Data}

Penelitian ini menggunakan teknik analisis jalur untuk mengetahui hubungan antara dua variabel bebas yaitu attachment style dan self-esteem dan satu variabel terikat yaitu kecemasan sosial. Analisis jalur dipilih karena dalam penelitian ini hubungan yang akan diteliti adalah hubungan sebab akibat secara tidak langsung. Secara terperinci Pedhazur (dalam Winarsunu, 2007) berpendapat bahwa analisis jalur merupakan sebuah metode yang digunakan untuk melihat akibat lang-sung dan tidak lang-sung dari suatu variabel yang dihipotesiskan sebagai penyebab terhadap variabel yang diperlakukan sebagai akibat. Variabel yang dianggap sebagai variabel penyebab pada penelitian ini adalah variabel attachment style dan selfesteem sementara variabel yang diperlakukan sebagai akibat adalah variabel kecemasan sosial.

Perhitungan analisis data dalam penelitian ini dilakukan dengan menghitung koefisien regresi baku (beta, $\beta$ ) melalui bantuan komputer program SPSS for windows versi 17,0. Koefisien regresi baku (beta, $\beta$ ) yang dihasilkan dari persamaan regresi merupakan koefisien jalur (path coefficients, $p$ ) (Winarsunu, 2007). Prosedur yang ditempuh dalam uji hipotesis adalah dengan jalan memeriksa batas penerimaan-penolakan taraf signifikansi statistik dari koefisien jalur yang dihasilkan. Koefisien jalur $(p)$ adalah koefisien regresi baku $(\beta)$. Untuk menentukan apakah $\beta$ termasuk signifikan atau tidak dapat dilihat dari signifikansi rasio $\mathrm{F}$ pada $\beta$. Apabila taraf signifikansi rasio $F$ pada $\beta<$ 0,05 maka koefisien jalur pada variabel tersebut dianggap signifikan.

\section{HASIL PENELITIAN}

Deskripsi data hasil penelitian seperti tampak pada Tabel 1. menunjukkan bahwa rata-rata variabel attachment style adalah 62,50 dengan nilai tertinggi dan terendah adalah sebesar 72 dan 51. Variabel kecemasan sosial memiliki rata-rata 75,36 dengan nilai tertinggi dan terendah adalah 49 dan 109. Sementara variabel self-esteem memiliki ratarata 137,22 dengan nilai tertinggi dan terendah adalah 164 dan 101.

Tabel 1. Statistik Deskriptif

\begin{tabular}{cccc} 
Minimum & Maximum & Mean & Std. Deviation \\
\hline 51 & 72 & 62.50 & 5.915 \\
49 & 109 & 75.36 & 10.828 \\
101 & 164 & 137.22 & 13.138
\end{tabular}

Berdasarkan data pada tabel 1. Tersebut, peneliti mengelompokkan skor subjek ke dalam dua kategori, yaitu kategori rendah dan tinggi. Pembagian kelompok dilakukan dengan menggunakan norma kelompok berdasarkan skor rata-ratanya. Subjek dikatakan memiliki skor rendah jika skornya di bawah rata-rata dan dikatakan memiiki skor tinggi jika skornya di atas rata-rata. Attachment style, memiliki rata-rata skor 62,50 sehingga berdasarkan norma kelompok subjek yang memiliki skor total di bawah 62,50 dianggap memiliki skor rendah dan subjek yang memiliki skor total di atas 62,50 dianggap memiliki skor tinggi. Berikut ini sebaran data subjek berdasarkan tinggirendahnya skor subjek.

Tabel 2. Sebaran Data Attachment Style

\begin{tabular}{cccc}
\hline No. & Kategori & Jumlah & Prosentase (\%) \\
\hline 1 & Rendah & 21 & 36,2 \\
2 & Tinggi & 37 & 63,8 \\
\hline & Total & 58 & 100 \\
\hline & & &
\end{tabular}

Berdasarkan data dalam tabel 2. 
diketahui bahwa dari 58 siswa yang menjadi sampel penelitian, diketahui bahwa mayoritas siswa memiliki attachment tinggi. Sebanyak $36,2 \%$ siswa memiliki attachment style yang rendah dan 63,8\% siswa memiliki attachment style yang tinggi. Setelah diketahui sebaran data menurut skor attachment style, peneliti juga melakukan pengelompokan data menurut skor self-esteem dan kecemasan sosial yang dilihat berdasarkan nilai rataratanya. Berikut ini sebaran data subjek berdasarkan skor self-esteem:

Tabel 3. Sebaran Data Self-esteem

\begin{tabular}{cccc}
\hline No. & Kategori & Jumlah & Prosentase $(\%)$ \\
\hline 1 & Rendah & 31 & 53,4 \\
2 & Tinggi & 27 & 46,6 \\
\hline & Total & 58 & 100 \\
\hline
\end{tabular}

Dari tabel di atas, diketahui bahwa dari 58 siswa yang menjadi sampel penelitian, $53,4 \%$ siswa tergolong dalam kategori tingkat self-esteem rendah dan $46,6 \%$ siswa tergolong dalam kategori tingkat self- esteem tinggi. Prosedur yang sama juga dilakukan untuk melihat sebaran data subjek berdasarkan skor kecemasan sosial yang terlihat dalam tabel berikut:

Tabel 4. Sebaran Data Kecemasan Sosial

\begin{tabular}{cccc}
\hline No. & Kategori & Jumlah & Prosentase (\%) \\
\hline 1 & Rendah & 26 & 45 \\
2 & Tinggi & 32 & 55 \\
\hline & Total & 58 & 100 \\
\hline
\end{tabular}

Sebaran data pada tabel di atas menunjukkan bahwa sebanyak $45 \%$ siswa memiliki tingkat kecemasan sosial rendah sementara 55\% siswa memiliki tingkat kecemasan sosial yang tinggi.

Pengujian normalitas data dalam penelitian ini menggunakan Test of Normality Kolmogorov-Smirnov dengan bantuan SPSS 17.0 for windows karena dapat memberikan angka hasil pengujian normalitas sehingga diketahui batas suatu sebaran dikatakan normal atau tidak. Dari analisis data ditemukan bahwa signifikansi atau nilai $\mathrm{p}$ attachment style sebesar 0,068 , nilai selfesteem menunjukkan signifikansi sebesar 0,199 dan kecemasan sosial menunjukkan signifikansi sebesar 0,200. Karena nilai $p$ value $>0,05$ maka distribusi ketiga variabel tersebut dapat dikatakan sebagai normal. Uji linieritas dengan bantuan SPSS versi 17.0 for windows menunjukkan bahwa signifikansi antara kecemasan sosial dan attachment style menunjukkan angka 0,917 yang berarti $\mathrm{p}>0,05$ sehingga dapat disimpulkan bahwa variabel kecemasan sosial dan attachment style dalam penelitian ini adalah linier. Signifikansi antara kecemasan sosial dan selfesteem menunjukkan angka 0,204 yang berarti $\mathrm{p}>0,05$ sehingga dapat disimpulkan bahwa variabel kecemasan sosial dan selfesteem dalam penelitian ini adalah linier. Selanjutnya uji homogenitas menggunakan uji Levene Statistic menunjukkan nilai 0,422 pada variabel attachment style. Karena 0,422 $>0,05$ maka variansi nilai yang diperbandingkan dapat dikatakan homogen. Variabel self-esteem menunjukkan nilai 0,770 yang berarti $>0,05$ maka variansi nilai yang diperbandingkan dapat dikatakan homogen.

Data yang ada telah memenuhi semua asumsi yang berlaku untuk analisis jalur, yaitu normalitas, linieritas, homogenitas, dan asumsi lain yang tidak diujikan seperti variabel berskala interval. Setelah semua asumsi terpenuhi langkah selanjutnya adalah melakukan analisis regresi untuk membuktikan hipotesis dengan melihat pada signifikansi rasio $\mathrm{F}$ pada $\beta$. Koefisien jalur dikatakan signifikan apabila nilai taraf signifikansi rasio $F$ pada $\beta<0,05$ dan dikatakan tidak signifikan jika nilai taraf signifikansi rasio $\mathrm{F}$ pada $\beta>0,05$. Bedasarkan hasil perhitungan analisis regresi dengan SPSS versi 17.0 for windows diperoleh informasi tentang nilai signifikansi dan 
koefisiensi jalur seperti pada tabel 5.1. dan 5.2. berikut ini:

Tabel 5.1. Ringkasan Hasil Analisis Regresi Linier

\begin{tabular}{cccc}
\hline Hubungan Antara Variabel & $R_{\text {Square }}$ & $\mathrm{F}$ & Signifikansi \\
\hline $\begin{array}{c}\text { Attachment Style dan Self-esteem } \\
\text { dengan Kecemasan Sosial }\end{array}$ & 0,464 & 23.799 & 0,000 \\
\hline
\end{tabular}

Tabel 5. 2. Koefisien Jalur Antara Variabel Bebas Terhadap Variabel Terikat

\begin{tabular}{ccccc}
\hline Hubungan Antara Variabel & Lambang & Koefisien jalur $(p)$ & Rasio F & Keterangan \\
\hline $\begin{array}{c}\text { Attachment Style dengan Kecemasan } \\
\text { Sosial }\end{array}$ & $P_{31}$ & $-0,467$ & 0,000 & Signifikan \\
$\begin{array}{c}\text { Self-esteem dengan Kecemasan Sosial } \\
\text { Attachment Style dengan }\end{array}$ & $P_{32}$ & $-0,368$ & 0,001 & Signifikan \\
Self-esteem & $P_{21}$ & 0,321 & 0,014 & Signifikan \\
\hline
\end{tabular}

Pada taraf signifikansi $<0,05$ dapat dilihat pada tabel 5.1. di atas bahwa hubungan antara attachment style dan self-esteem dengan kecemasan sosial adalah signifikan karena rasio $\mathrm{F}$ sebesar 0,000. Pada tabel 5.2. terlihat nilai rasio $\mathrm{F}$ adalah 0,000 yang berarti hubungan antara attachment style dengan kecemasan sosial dapat dikatakan signifikan. Hubungan antara self-esteem dengan kecemasan sosial juga signifikan karena nilai rasio $\mathrm{F}$ sebesar 0,001 . Sedangkan nilai rasio $\mathrm{F}$ pada hubungan kausal antara attachment style dengan self-esteem menunjukkan angka sebesar 0,014 sehingga dapat dikatakan ada hubungan yang signifikan antara attachment style dengan self-esteem. Berdasarkan hasil perhitungan koefisien jalur pada tabel 5.2. analisis data dapat dilanjutkan pada proses dekomposisi korelasi antara variabel bebas dan variabel terikat untuk menemukan besarnya koefisien pada pola hubungan langsung (DE) dan hubungan tidak langsung (IE).

Tabel 6. Sumbangan Efektif terhadap Kecemasan Sosial

\begin{tabular}{|c|c|c|c|}
\hline Variabel & DE & IE & Total \\
\hline Attachment Style & $\begin{array}{c}-0,467(-0,585) \\
0,273\end{array}$ & $\begin{array}{c}-0,118(-0,585) \\
0,07\end{array}$ & 0,343 \\
\hline Self-esteem & $\begin{array}{c}-0,368(-0,321) \\
0,118\end{array}$ & - & 0,118 \\
\hline Jumlah & 0,391 & 0,07 & 0,461 \\
\hline
\end{tabular}

Dari tabel 6. di bawah ini dapat disimpulkan bahwa attachment style dengan kecemasan sosial memiliki hubungan langsung (DE) sebesar -0,467 dan hubungan tidak langsung (IE) sebesar -0,118. Sedangkan hubungan antara self-esteem dengan kecemasan sosial tidak memiliki hubungan tidak langsung tetapi memiliki hubungan langsung (DE) sebesar 0,368. Berdasarkan hasil perhitungan sumbangan efektif seperti tampak pada tabel 6. maka dapat disimpulkan bahwa $46,1 \%$ dari variasi kecemasan sosial dapat dijelaskan atau diprediksikan melalui variasi variabel attachment style dan self-esteem dengan rincian melalui attachment style 34,3\% dan melalui self-esteem 11,8\%. Dengan demikian, sumbangan yang diberikan oleh variabel attachment style lebih tinggi jika dibandingkan dengan sumbangan dari variabel self-esteem dalam memprdiksikan variable kecemasan sosial. 


\section{PEMBAHASAN}

Penelitian ini bertujuan untuk mengetahui hubungan kausalitas antara attachment style dan self-esteem dengan kecemasan sosial pada remaja. Berdasarkan hasil pengujian hipotesis dengan menggunakan teknik analisis jalur diketahui bahwa attachment style memiliki hubungan baik secara langsung maupun tidak langsung dengan kecemasan sosial. Sementara selfesteem hanya memiliki hubungan langsung dengan kecemasan sosial. Attachment style dan self-esteem memiliki hubungan yang negatif dan signifikan antara attachment style dan self-esteem dengan kecemasan sosial. Hubungan negatif menunjukkan bahwa attachment style dan self-esteem memiliki skor yang berbanding terbalik dengan skor kecemasan sosial. Hal ini berarti semakin tinggi attachment style seseorang maka akan semakin rendah kecemasan sosial mereka, demikian juga dengan semakin tinggi selfesteem seseorang maka akan semakin rendah pula kecemasan sosialnya. Hal ini sesuai dengan teori yang menyatakan bahwa attachment pada masa remaja dapat membantu kompetensi sosial dan kesejahteraan sosial remaja sebagaimana tercermin dalam ciri-ciri seperti self-esteem, penyesuaian emosional, dan kesehatan fisik. Attachment yang kokoh antara anak dengan orang tua akan meningkatkan relasi teman sebaya yang kompeten dan relasi erat yang positif di luar keluarga (Santrock, 2002).

Sementara itu, Bowlby (dalam Surcineli, 2010) berpendapat bahwa pengalaman awal dengan pengasuh utama diinternalisasikan oleh anak untuk membentuk internal working models yaitu struktur kognitif yang berperan sebagai dasar dalam membangun hubungan dengan orang lain di luar keluarganya. Empat dasar pola attachment didefinisikan dalam dua bentuk internal working models, yaitu internal working models atas diri sendiri dan internal working models atas orang lain. Internal working models yang positif terhadap diri adalah perasaan dicintai dan merasa berharga, sementara internal working models positif terhadap orang lain melibatkan harapan seseorang terhadap dukungan dan keberadaan orang lain. Internal working models negatif terhadap diri sendiri dikarakteristikkan dengan kecemasan tentang kedekatan dan memiliki ketergantungan yang berlebihan, sementara internal working models negatif terhadap orang lain dikarakteristikkan dengan menghindari keintiman. Orang-orang yang secure memiliki pandangan positif terhadap diri dan orang lain. Semakin tingginya nilai attachment style menunjukkan bahwa individu tersebut semakin secure. Hal itu berarti individu memiliki perasaan bahwa dirinya dicintai dan berharga serta memiliki harapan akan dukungan dan keberadaan orang lain sehingga kemungkinan individu mengalami kecemasan sosial semakin rendah.

Adapun self-esteem adalah kepercayaan akan kemampuan diri sendiri untuk berpikir dan mengatasi tantangan dasar dalam hidup serta kepercayaan pada hak untuk bahagia, perasaan berharga, pantas untuk menyatakan kebutuhan dan keinginan, dan menikmati buah dari usaha-usaha yang telah dilakukan (Branden, 1992). Dari pengertian ini dapat diketahui bahwa orang yang memiliki selfesteem tinggi kemungkinan akan cenderung mengalami kecemasan sosial yang rendah.

Kesimpulan yang dapat diambil dari pembahasan di atas adalah baik attachment style maupun self-esteem sama-sama memiliki kontribusi dalam pandangan positif individu terhadap dirinya yang tercermin melalui perasaan dicintai dan perasaan berharga. Perasaan berharga dan perasaan dicintai akan menuntun individu pada kepercayaan pada diri dan orang yang muncul dalam perilakunya sehingga ketika individu merasa percaya pada dirinya dan orang lain, 
evaluasi negatif dari orang lain tidak akan menjadi masalah yang besar bagi mereka. Sebaliknya, individu justru akan menganggap evaluasi tersebut sebagai saran dan motivasi untuk mengembangkan potensinya lebih baik lagi. Ketakutan akan adanya evaluasi negatif merupakan penyebab utama dalam munculnya kecemasan sosial (Weeks, 2010). Sehingga dengan berkurangnya ketakutan akan evaluasi negatif dari seorang individu maka akan semakin kecil pula kemungkinan individu tersebut mengalami kecemasan sosial.

Keseluruhan sumbangan efektif yang diberikan oleh attachment style dan selfesteem terhadap kecemasan sosial adalah sebesar $46,1 \%$, sedangkan sisanya $53,9 \%$ tidak dapat dijelaskan melalui dua variabel tersebut. Sebagian dari sisa ini mungkin dapat dijelaskan melalui variabel lain di luar attachment style dan self-esteem dan sebagian lainnya merupakan variasi akibat kesalahan pengukuran. Attachment style dan self-esteem bukanlah satu-satunya variabel yang mempengaruhi kecemasan sosial. Kagan (dalam Durand \& Barlow, 2006) menjelaskan bahwa kerentanan biologis juga ikut mempengaruhi berkembangnya kecemasan sosial pada individu. Menurut Kagan, sebagian bayi lahir dengan profil tempramental dan ciri sifat pemalu yang sudah tampak pada usia 4 bulan. Bayi yang memiliki sifat pemalu ini memiliki resiko yang lebih tinggi untuk mengembangkan kecemasan sosial. Variabel lain yang diduga memiliki sumbangan terhadap kecemasan sosial adalah konsep diri dan dukungan sosial. Karena adanya faktor-faktor seperti yang telah disebutkan di atas maka wajar jika sumbangan yang dihasilkan oleh attachment style dan self-esteem terhadap kecemasan sosial tidak dapat mencapai angka $100 \%$.

Berdasarkan data hasil penelitian diketahui bahwa attachment style pada para siswa subjek penelitian semuanya mengarah ke secure attachment. Ada beberapa kemungkinan yang mempengaruhi kecenderungan siswa yang semuanya mengarah pada gaya secure attachment, salah satunya adalah jumlah sampel penelitian yang kurang banyak sehingga kecenderungan attacment style pada siswa kurang bervariasi. Hasil penelitian yang dilakukan oleh Surcineli dkk. (2010) mengenai Attachment Style pada orang dewasa dan penyakit psikologis yang dilakukan pada 274 sukarelawan, menunjukkan bahwa 161 atau 58,8 \% sampel penelitian menunjukkan secure attachment style, sisanya $17,9 \%$ fearful attachment, $14,2 \%$ preoccupied, dan $9,1 \%$ untuk dismissing attachment. Penelitian lain yang dilakukan oleh Gore (2010) tentang Pengaruh Attachment Style Terhadap Prestasi Akademik yang dilakukan pada 195 mahasiswa menunjukkan bahwa 120 mahasiswa termasuk ke dalam secure attachment dan sisanya sebanyak 75 mahasiswa menyebar ke dalam tiga tipe attachment style lainnya. Dari kedua penelitian ini dapat disimpulkan bahwa attachment style yang paling banyak ditunjukkan oleh responden adalah secure attachment sehingga tidak mengherankan jika pada penelitian ini seluruh siswa mengalami kecenderungan secure attachment style.

Sebaran data subjek mengenai skor selfesteem dan kecemasan sosial siswa menunjukkan bahwa mayoritas siswa memiliki nilai self-esteem yang rendah dan kecemasan sosial yang tinggi. Rendahnya self-esteem siswa kemungkinan besar dipengaruhi oleh aspek kesadaran, tanggung jawab, integritas, asertivitas, dan penerimaan diri remaja yang masih lemah. Hal itu sesuai dengan teori Erikson (dalam Santrock, 2002) yang menyatakan bahwa remaja mengalami tahap perkembangan identitas versus kebingungan identitas. Di samping itu, pada masa ini remaja biasanya mulai memiliki klik dan kelompok teman sebaya. Kesetiaan pada klik, klub, organisasi, dan tim memiliki 
kendali yang kuat terhadap kehidupan banyak remaja (McLellan, Haynie \& Strouse dalam Santrok, 2002). Identitas kelompok sering kali mengarahkan identitas pribadi sehingga sering kali identitas yang muncul pada seorang remaja bukanlah identitas mereka yang sebenarnya melainkan identitas kelompoknya. Kelompok-kelompok ini tidak jarang menghadirkan tekanan dan tuntutan konformitas. Konformitas dengan tekanan teman-teman sebaya pada masa remaja dapat bersifat positif maupun negatif, namun umumnya remaja justru terlibat dalam bentuk perilaku konformitas yang negatif (Santrock, 2002). Konformitas membuat asertifitas pada masa remaja terkesan tidak muncul karena terkalahkan dengan pendapat kelompok. Karena itulah mengapa self-esteem pada mayoritas sampel pada penelitian ini termasuk rendah.

Sementara itu, banyaknya sampel yang mengalami kecemasan sosial tinggi selain bisa dikaitkan dengan self-esteem remaja yang memang rendah juga bisa dikaitkan dengan aspek-aspek yang menyertai kecemasan sosial. Terdapat tiga aspek dalam kecemasan sosial, yaitu perilaku, perasaan, dan respon fisiologis. Sebagaimana yang telah dijelaskan di atas, perilaku remaja banyak dipengaruhi oleh klik dan kelompok teman sebayanya. Hal ini menyebabkan remaja meluangkan waktu lebih banyak dengan teman-teman sebaya dan sedikit bersosialisasi dengan orang-orang di luar kelompoknya. Inilah yang membuat remaja merasa canggung ketika ia berada di lingkungan baru yang banyak berisi orang-orang di luar klik maupun kelompok terdekatnya.

Melihat dari beberapa penjelasan di atas maka dapat diketahui adanya hubungan yang saling berkaitan antara satu variabel dengan variabel lainnya. Attachment yang baik akan menuntun seseorang dalam mendapatkan selfesteem yang tinggi dan dengan self-esteem yang tinggi individu akan merasa dirinya berharga, dicintai, dan pantas mendapatkan hasil dari usahanya sehingga adanya evaluasi negatif dari orang lain tidak akan membuat individu mengalami kecemasan sosial yang tinggi. Attachment style memiliki pengaruh terhadap kecemasan sosial baik secara langsung maupun tidang langsung. Demikian juga dengan self-esteem yang memiliki pengaruh terhadap kecemasan sosial secara langsung. Jika dilihat perbandingan antara sumbangan yang diberikan oleh attachment style dan self-esteem terhadap kecemasan sosial, variabel attachment style memiliki sumbangan efektif yang lebih tinggi yaitu sebesar 34,3\% dibandingkan dengan selfesteem yang hanya $11.8 \%$. Hal ini berarti attachment style merupakan suatu variabel yang lebih menentukan kecemasan sosial dibanding self-esteem.

\section{SIMPULAN}

Penelitian ini menyimpulkan bahwa attachment style dan self-esteem memiliki hubungan yang negatif dan signifikan dengan kecemasan sosial. Hal ini berarti attachment style dan self-esteem berbanding terbalik dengan kecemasan sosial yang menyebutkan semakin tinggi attachment style dan selfesteem remaja maka akan semakin rendah kecemasan sosialnya. Sebaliknya, semakin rendah attachment style dan self-esteem remaja maka akan semakin tinggi kecemasan sosialnya.

Attachment style memiliki hubungan langsung dan tidak langsung dengan kecemasan sosial, sementara self-esteem hanya memiliki hubungan langsung dengan kecemasan sosial. Dari hasil hubungan langsung dan tidak langsung tersebut dapat diketahui bahwa attachment style dan selfesteem memiliki sumbangan efektif terhadap kecemasan sosial. Hal ini berarti sebagian variasi kecemasan sosial dapat dijelaskan atau diprediksikan melalui attachment style dan 
self-esteem

\section{SARAN}

Berdasarkan hasil penelitian dapat direkomendasikan bahwa dalam meminimalisir kecemasan sosial dan dampaknya terhadap prestasi akademik siswa, guru maupun orang tua perlu menjalin kelekatan (attachment) yang kokoh dengan siswa atau anaknya. Menjaga harga diri (selfesteem) siswa tetap positif juga perlu dilakukan agar mereka terhindar dari kecemasan sosial. Untuk penelitian selanjutnya perlu lebih menekankan pada salah satu tipe attachment style saja sebagai prioritas penelitian sehingga dapat menambah ketelitian dan kedalaman hasil penelitian. Penelitian ini juga belum bisa mengungkap faktor-faktor lain yang bisa mengakibatkan kecemasan sosial sehingga penggunaan faktor lain untuk mengungkap varian dalam kecemasan sosial pada penelitian selanjutnya dapat dipertimbangkan.

\section{DAFTAR PUSTAKA}

Azwar, Syarifudin. (2008). Pengukuran Skala Psikologi. Yogyakarta: Pustaka Pelajar.

Branden, N. (1992). The Power of Self Esteem. Florida: Health Communication, Inc.

Dayakisni, T, \& Hudaniah. (2009). Psikologi sosial. Malang: UMM Press.

Durand, V. M. \& Barlow, D. H. (2006). Intisari Psikologi Abnormal. Terjemahan oleh Helly Prajitno Soetjipto dan Sri Mulyatini Soetjipto. Yogyakarta: Pustaka Pelajar.

Feist, Jess \& Feist, Gregory J. (2008). Theories of Personality. Edisi Keenam. Terjemahan oleh Yudi Santoso. Yogyakarta: Pustaka Pelajar.

Gunarsa, S. D, \& Gunarsa, Y. S. D. (2006). Psikologi perkembangan anak dan remaja. Jakarta: PT BPK Gunung Mulia.

Hurlock, Elizabeth B. (1990). Psikologi Perkembangan. Edisi Kelima. Terjemahan oleh Istiwidayanti dan Soedjarwo. Jakarta: PT Gelora Aksara Pratama.

Liliana, A. W. (2009). Gambaran Kelekatan (Attachment) Remaja Akhir Putri Dengan Ibu. Skripsi tidak diterbitkan. Depok: Universitas Gunadarma.

Nevid, J. S. (2005). Psikologi Abnormal. Jilid 1. Terjemahan oleh Tim Psikologi UI. Jakarta: Erlangga.
Papalia, D. E., Olds, \& Feldman. (2007). Human Development. 10th edition. McGraw Hill Companies.

Santrock, John W. (1995). Life Span Development. Jilid 2. Terjemahan oleh Ahmad Chusairi dan Juda Damanik. Jakarta: Erlangga.

Santrock, John W. (2005). Adolescence. 10th Edition. McGraw-Hill Companies.

Surcinelli, Paola. dkk. (2010). Adult Attachment Style and Psychological Desease: Examining The Mediating Role of Personality Traits. Journal of Psychology, (online), Vol. 144 No. 6, (http//www. search.ebscohost.com, diakses 17 November 2010).

Weeks, Justin W. dkk. (2010). Comparing and Contrasting Fears of Positive and Negative Evaluation As Facets of Social Anxiety. Journnal of Social and Clinical Psychology, (online), Vol. 29, No. 1, (http//www.search.ebscohost.com, diakses 17 November 2010).

Winarsunu, Tulus. (2007). Statistik dalam Penelitian Psikologi dan Pendidikan. Malang: UMM Press. 